\title{
Preparation and Characterization of Proteinaceous Films from Seven Mexican Common Beans (Phaseolus vulgaris L.)
}

\author{
Claudia Montalvo-Paquini, ${ }^{1,2}$ Raúl Avila-Sosa, ${ }^{3}$ \\ Aurelio López-Malo $\mathbb{D}^{1},{ }^{1}$ and Enrique Palou $\mathbb{D D}^{1}$ \\ ${ }^{1}$ Departamento de Ingeniería Química y Alimentos, Universidad de las Américas Puebla, 72810 San Andrés Cholula, PUE, Mexico \\ ${ }^{2}$ Ingeniería en Biotecnología, Universidad Politécnica de Puebla, Tercer Carril del Ejido Serrano s $n$, San Mateo Cuanalá, \\ 72640 Juan C. Bonilla, PUE, Mexico \\ ${ }^{3}$ Departamento de Bioquímica-Alimentos, Facultad de Ciencias Químicas, Benemérita Universidad Autónoma de Puebla, \\ Edificio FCQ4, Ciudad Universitaria, 72570 Puebla, PUE, Mexico
}

Correspondence should be addressed to Enrique Palou; enrique.palou@udlap.mx

Received 21 October 2017; Accepted 12 December 2017; Published 3 January 2018

Academic Editor: Jorge Barros-Velázquez

Copyright (C) 2018 Claudia Montalvo-Paquini et al. This is an open access article distributed under the Creative Commons Attribution License, which permits unrestricted use, distribution, and reproduction in any medium, provided the original work is properly cited.

\begin{abstract}
Bean protein concentrate (BPC) as a protein source from seven varieties of Mexican common beans (alubia, flor de mayo, garbancillo, peruano, pinto, mantequilla, and negro) was utilized for formulating edible films (EF). EF were prepared with BPC $(3 \% \mathrm{w} / \mathrm{w})$ and glycerol as a plasticizer by the casting method; their thickness, water content, soluble matter, protein solubility, color, puncture strength, elongation, water vapor permeability (WVP), and chemical properties (Fourier transform infrared, FTIR, and spectroscopy) were evaluated. Tested EF had an average thickness of $0.045 \pm 0.001 \mathrm{~mm}$. Good stability was observed since the studied polymers did not exceed $35 \%$ of the total soluble matter while protein solubilities were not greater than $3 \%$. EF made from peruano bean protein presented a lower value of total matter solubility $(25.38 \pm 2.24 \%)$ than the other tested EF. A low value of WVP $\left(2.06 \pm 0.25 \times 10^{-10} \mathrm{~g} \mathrm{~m} / \mathrm{Pa} \mathrm{s} \mathrm{m^{2 }}\right)$ was observed in films from negro bean protein, while EF from flor de mayo bean protein exhibited the highest values of puncture strength $(17.35 \pm 0.82 \mathrm{MPa})$ and elongation $(38.21 \pm 0.64 \%)$. Most bean protein EF had reddish or brownish color; however, films from alubia and peruano bean proteins displayed light yellowish colors. FTIR spectra of EF revealed that glycerol did not react with the studied bean proteins through covalent bonds.
\end{abstract}

\section{Introduction}

There is an increased interest in using biodegradable materials to substitute synthetic plastics in food packaging $[1,2]$. Main ingredients that can be used for edible film fabrication include lipids, carbohydrates, and proteins. Protein polymers have excellent oxygen barrier properties that are very favorable for coating foods; additionally, they could be used to increase product nutritional value [3]. However, proteinbased edible films are very brittle and exhibit weak mechanical strength and poor flexibility as food packaging materials; in order to improve these properties, plasticizers like sugars [4] or glycerol [5] have been added. Plasticizers can increase the mobility of polypeptide chains, improving the flexibility of protein films, but they generally present hydrophilic characters, which contribute to the increase of water permeability and susceptibility of the matrix to environmental humidity $[1,6,7]$.

Properties of protein-based films depend on various factors such as $\mathrm{pH}$ of protein solution, preparation conditions, and the source of protein [8]. Until now, edible protein films have been made from sources including animal proteins (milk, collagen, gelatin, and myofibrillar proteins) as well as vegetable proteins (corn zein, wheat gluten, and soy proteins) [9-11]. Many authors have studied edible films made with soy protein [12-14], but the information available for the implementation of other legume proteins as raw material for edible films is still limited $[5,15,16]$.

On the other hand, the legume family is the third largest in the plant kingdom, with 670 genera and 18,000 species 
growing in worldwide media and climatic regions, though only about 200 species are used regularly for human food, livestock fodder, or oilseed industry [17]. Legumes are the second most important crop for humans and animals after cereals, having two to three times higher protein content, which may vary from 17 to $40 \%$ depending on the species, genetic strain, and culture conditions [18]. In the case of beans, their protein content varies from 22 to $32 \%$ depending on the variety. Approximately $75 \%$ of their protein content is from globulins, called phaseolins that, besides being the main storage protein seeds, are used as markers for evolutionary and diversity studies [19]. Mexico is considered one of the centers of origin of various types of beans (Phaseolus vulgaris L.) with high commercial value [20]; this crop represents the second in importance at the national level. Some estimates report that $14 \%$ of Mexican agricultural productive units are engaged in the production of beans [21]. During 2014, the total production of bean was 1,295,000 tons [22] and approximately $65 \%$ of this crop is concentrated in the central-north and pacific-north regions [21]. Moreover, beans represent an inexpensive source of protein with a relatively high nutritional value because of its high content of essential amino acids like lysine, tyrosine, and phenylalanine [17]. For these reasons, it could be considered as an alternative source of raw material for fabricating proteinaceous edible films. Thus, the objective of this work was to develop edible films using protein concentrates from different varieties of beans and compare their physical, chemical, and mechanical properties.

\section{Materials and Methods}

Common beans from seven different market classes consumed in Mexico, namely, alubia, flor de mayo, garbancillo, peruano, pinto, mantequilla, and negro, were purchased at a local market in San Pedro Cholula, Puebla. Glycerol used as a plasticizer was obtained from Merck (Merck Inc., Whitehouse Station, NJ).

2.1. Preparation of Bean Protein Concentrates (BPC). Beans were milled in an industrial blender and passed through a sieve (40 mesh) to obtain a fine powder. Alkaline-acid extraction was performed on powders from each of the tested bean varieties to obtain protein isolates, following the technique reported by Bamdad et al. [23]; powders were stirred in distilled water by adjusting the $\mathrm{pH}$ value to 11.0 with $1 \mathrm{~N} \mathrm{NaOH}$ to increase solubility of the protein and then centrifuged at $8,000 \mathrm{rpm}$ for $30 \mathrm{~min}$ and the supernatant obtained was acidified with $1 \mathrm{~N} \mathrm{HCl}$ to a $\mathrm{pH}$ value of 5.4 to facilitate the aggregation of proteins, which were subsequently separated by centrifugation at $8,000 \mathrm{rpm}$ for $20 \mathrm{~min}$ and freeze-dried.

2.2. Film Formation. Film forming solutions were prepared by dissolving BPC $(3 \% \mathrm{w} / \mathrm{v})$ in distilled water under constant stirring; the $\mathrm{pH}$ value was adjusted to 10.0 using $1 \mathrm{~N} \mathrm{NaOH}$; glycerol was added ( $50 \% \mathrm{w} / \mathrm{w}$ of BPC) as a plasticizer. The solutions obtained were homogenized (Silverson homogenizer, Model L4R, England) at 9,000 rpm for $1 \mathrm{~min}$, degassed under vacuum, and then heat-denatured at $80^{\circ} \mathrm{C}$ for $20 \mathrm{~min}$ in a water bath and cooled to $37^{\circ} \mathrm{C}$ for 3-4 min [23]. Bean protein films were made by casting a protein isolate solution $(2.5 \mathrm{ml})$ on a Teflon-coated baking pan ( $5 \mathrm{~cm}$ diameter) and then


at $50 \% \mathrm{RH}$ for $48 \mathrm{~h}$ prior to testing [23].

2.3. Thickness and Moisture Content. Thickness of the films was measured with a caliper micrometer (Mitutoyo, Model MDC-1, Japan) at 10 random positions of the film [16]. Moisture content was determined by weight loss after drying the films at $105^{\circ} \mathrm{C}$ for $24 \mathrm{~h} \mathrm{[25].}$

2.4. Water Vapor Permeability (WVP). WVP of the films was measured according to the method described by Tapia et al. [26], from the weight increase of glass cells. The glass cells were $1.42 \mathrm{~cm}$ in width (internal diameter) and $7.0 \mathrm{~cm}$ in height, with an exposed area of $1.6 \mathrm{~cm}^{2}$. These cells were filled with distilled water to a level of $1 \mathrm{~cm}$ below the top. The tested films were cut into circles and placed (triplicates) on top of the glass cells, sealed hermetically with parafilm, and then placed in desiccators containing a saturated $\mathrm{MgCl}_{2}$ solution (33\%). Weights were recorded every hour over a period of $8 \mathrm{~h}$. The relationship between the weight loss and time was linear and the slope of the plots was calculated by linear regression. The water vapor transfer rate (WVTR) and WVP were calculated in accordance with the following expressions:

$$
\begin{aligned}
\mathrm{WVTR} & =\frac{m l}{A} \\
\mathrm{WVP} & =\frac{\mathrm{WVTR} \cdot L}{\left(p_{1}-p_{2}\right)},
\end{aligned}
$$

where $m l$ is the slope of the weight loss versus time (g/s), A is the exposed area $\left(\mathrm{m}^{2}\right), L$ is the average film thickness $(\mathrm{m})$, $p_{1}$ is the partial pressure inside the desiccator, and $p_{2}$ is the partial pressure inside the cells [26].

2.5. Total Soluble Matter (TSM). TSM was calculated as the percentage of film dissolved during immersion in distilled water [15]. Film specimens $(2 \mathrm{~cm} \times 2 \mathrm{~cm})$ were placed in $10 \mathrm{ml}$ of distilled water with potassium sorbate $(0.01 \% \mathrm{w} / \mathrm{v})$ to prevent microbial growth. The samples were soaked in a water bath at $20^{\circ} \mathrm{C}$ for $24 \mathrm{~h}$ with gentle stirring. The films were removed from the solution and dried $\left(102 \pm 2^{\circ} \mathrm{C}\right)$ for $24 \mathrm{~h}$ to determine the weight of dry matter that was dissolved in water. This determination was performed in triplicate for each tested film. The percentage of TSM of the films was calculated by means of

$$
\begin{aligned}
\% \operatorname{TSM}= & \left(\frac{\text { Initial dry weight }- \text { Final dry weight }}{\text { Initial dry weight }}\right) \\
& * 100 .
\end{aligned}
$$

2.6. Film Protein Solubility. The supernatant obtained in the TSM test was analyzed for protein content (in triplicate) according to the technique described by Lowry et al. [27]. Protein concentrations were calculated from a standard curve obtained using bovine serum albumin. The percentage of 
TABLE 1: Properties of the tested proteinaceous edible films obtained from the studied bean varieties ${ }^{\mathrm{a}}$.

\begin{tabular}{lccc}
\hline Bean variety & Moisture content (\%) & Thickness (mm) & $\begin{array}{c}\text { Water vapor } \\
\text { permeability } \\
\left(\times 10^{-10} \mathrm{~g} / \mathrm{Pa} \cdot \mathrm{s} \cdot \mathrm{m}\right)\end{array}$ \\
\hline Alubia & $21.71 \pm 3.16^{\mathrm{ab}}$ & $0.047 \pm 0.004^{\mathrm{a}}$ & $2.68 \pm 0.42^{\mathrm{a}}$ \\
Flor de mayo & $25.13 \pm 2.87^{\mathrm{ab}}$ & $0.047 \pm 0.004^{\mathrm{a}}$ & $2.65 \pm 0.32^{\mathrm{a}}$ \\
Garbancillo & $20.76 \pm 1.60^{\mathrm{b}}$ & $0.046 \pm 0.003^{\mathrm{a}}$ & $2.69 \pm 0.24^{\mathrm{a}}$ \\
Mantequilla & $26.18 \pm 1.89^{\mathrm{ab}}$ & $0.044 \pm 0.004^{\mathrm{a}}$ & $2.17 \pm 0.36^{\mathrm{a}}$ \\
Negro & $22.41 \pm 2.86^{\mathrm{ab}}$ & $0.042 \pm 0.001^{\mathrm{a}}$ & $2.06 \pm 0.25^{\mathrm{a}}$ \\
Peruano & $29.11 \pm 3.05^{\mathrm{a}}$ & $0.047 \pm 0.004^{\mathrm{a}}$ & $2.41 \pm 0.11^{\mathrm{a}}$ \\
Pinto & $20.89 \pm 0.84^{\mathrm{b}}$ & $0.044 \pm 0.003^{\mathrm{a}}$ & $2.21 \pm 0.07^{\mathrm{a}}$ \\
\hline
\end{tabular}

${ }^{a}$ Means followed by the same letter in the same column are not significantly $(p>0.05)$ different.

soluble protein of the film was calculated according to Sothornvit and Krochta [28].

2.7. Mechanical Properties. The mechanical properties of the films were evaluated by puncture test as described by Soradech et al. [29]. A texture analyzer (Texture Technologies Corp., NY, USA) equipped with a spherical puncturing probe (diameter: $1.4 \mathrm{~cm}$ ) was employed. The tested film was placed in a holder with a cylindrical hole $(r=0.8 \mathrm{~cm})$. The probe was driven through the film with a speed of $1 \mathrm{~mm} / \mathrm{s}$ and force displacement curves were recorded through a $25 \mathrm{~N}$ load cell. The puncture strength and percentage of elongation were calculated using (3) and (4), respectively. An average of six measurements were performed.

$$
\text { Puncture strength }=\frac{F_{\max }}{\text { Acs }},
$$

where $F_{\max }$ is the maximum applied force and Acs is the crosssectional area of the edge of the film located in the path of the cylindrical hole of the film holder, with Acs $=2 r \delta$, where $r$ is the radius of the hole and $\delta$ is the thickness of the film.

$$
\% \text { Elongation }=\left(\frac{\sqrt{r^{2}+d^{2}}-r}{r}\right) * 100,
$$

where $r$ is the radius of the film exposed in the cylindrical hole of the film holder and $d$ represents the displacement of the probe from the point of contact to the point of puncture.

2.8. Color Measurements. Color values of the films were measured with a colorimeter (ColorGard System/05, BYK Gardner Inc., Silver Spring, MD) calibrated with a white standard plate $\left(L^{*}=92.89, a^{*}=-1.06\right.$, and $\left.b^{*}=0.82\right)$. Film color was measured by the $L^{*}, a^{*}$, and $b^{*}$ color scale. $L^{*}$ values range from 0 (black) to 100 (white) while chromaticity parameters $a^{*}$ range from green $(-60)$ to red $(+60)$ and $b^{*}$ from blue $(-60)$ to yellow $(+60)$. Five measurements were made for each film sample and for each type of tested film 5 replicates were performed [23]. Chroma $\left(C^{*}\right)$ and hue $\left(h^{*}\right)$ angle of the films were then calculated:

$$
\begin{aligned}
\text { Chroma } & =\sqrt{a^{* 2}+b^{* 2}} \\
\text { Hue } & =\arctan \left(\frac{b^{*}}{a^{*}}\right) .
\end{aligned}
$$

2.9. Infrared Spectroscopy. Fourier transform infrared (FTIR) spectroscopy analysis was carried out at room temperature to obtain information about the main functional groups of the matrix of the tested films. Spectra were evaluated using a Shimadzu FTIR spectrometer (IRAffinity-1, Japan) by means of at least ten scans in the range of 4000 and $500 \mathrm{~cm}^{-1}$ for each of the analyzed samples [7].

2.10. Statistical Analysis. The Minitab 16.0 program (Minitab, Inc., State College, PA, USA) was utilized to perform the analysis of variance (ANOVA) tests. The statistical differences between mean values were established at $p<0.05$ [30].

\section{Results and Discussion}

Every edible film displayed good visual appearance and was easy to handle during determination of the studied properties. Table 1 shows the moisture content, thickness, and WVP for the tested protein edible films made from the studied bean varieties.

3.1. Thickness and Moisture Content. Film moisture content was significantly $(p<0.05)$ affected by the bean variety used in the film forming solution during preparation of the tested films (Table 1). The moisture content values were in the range of 20.76 to $29.11 \%$ for edible films from garbancillo and peruano beans, respectively. Similar results were obtained by Jangchud and Chinnan [31] who studied peanut protein edible films and reported moisture contents around $28.6 \%$ while Bamdad et al. [23] reported values of $23.15 \%$ for lentil edible films.

The seed proteins of legumes are mostly albumins and globulins that account for about $40-90 \%$ of seed protein, which are water soluble and soluble in dilute neutral salt solutions, respectively [32]. The studied bean varieties may have dissimilar protein profiles; Sánchez-Arteaga et al. [33] reported for negro beans a higher proportion of total globulin and glutelins than for flor de mayo and pinto beans. These features can impact their functionality and could have an influence on the moisture content obtained for the tested edible films. On the other hand, thickness values obtained for the tested films did not show significant differences $(p>0.05)$ among the studied bean varieties. This could be because, 


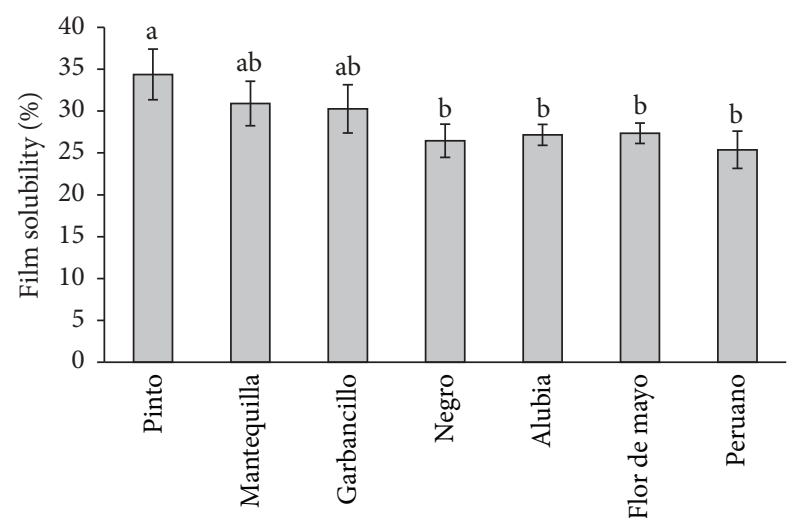

Figure 1: Film solubility of the tested proteinaceous edible films from the studied bean varieties. Means with the same letter are not significantly $(p>0.05)$ different.

at the high drying temperatures used $\left(60^{\circ} \mathrm{C}\right)$, the cohesive strength increased, resulting in the ability to form strong bonds between polymer chains.

3.2. Water Vapor Permeability. Proteinaceous edible films obtained from negro beans exhibited the lowest values of WVP $\left(2.06 \times 10^{-10} \mathrm{~g} \mathrm{~m} / \mathrm{Pa} \mathrm{s} \mathrm{m}{ }^{2}\right)$ but were not significantly different $(p>0.05)$ with respect to edible films from the other bean varieties tested (Table 1). This edible film might have a higher content of nonpolar amino acids with respect to the other bean varieties, which form a fine stranded network and therefore could be resistant to water transfer through the film.

WVP values obtained in this study are slightly lower than those reported by González et al. [34] who obtained a value of $2.41 \times 10^{-10} \mathrm{~g} \mathrm{~m} / \mathrm{Pa} \mathrm{s} \mathrm{m}{ }^{2}$ for soy protein isolate films using glycerol as a plasticizer. However, the WVP obtained values are still higher than those obtained by Limpan et al. [35] for edible films from fish protein $\left(8 \times 10^{-11} \mathrm{~g} \mathrm{~m} / \mathrm{Pa} \mathrm{s} \mathrm{m}^{2}\right)$.

3.3. Total Soluble Matter. Total soluble matter of edible films from pinto, mantequilla, and garbancillo beans had high solubility values (above $30 \%$ ) while edible films from peruano beans show good structural integrity because they had the lowest values of film solubility $(25.38 \pm 2.24 \%)$ as can be seen in Figure 1. Pérez-Gago and Krochta [36] observed that edible protein films formed using low denaturation temperatures and short times for film forming solutions dissolved rapidly after being in contact with water, but film forming solutions heated at high temperature and for long times maintained their integrity throughout the whole film soaking treatment. For the heat-denatured bean edible films obtained in this work, glycerol represents most of the soluble matter, since glycerol is very hydrophilic.

Film solubility values obtained for other legume protein films such as peanuts [31], peas [24], and green beans [9] were larger than for tested bean edible films, being 40,41 , and $36 \%$ higher, respectively. For edible films made from animal proteins such as whey protein, their soluble matter may be less than $10 \%$, but only if the films are previously subjected to denaturation temperatures above $90^{\circ} \mathrm{C}$ [37].

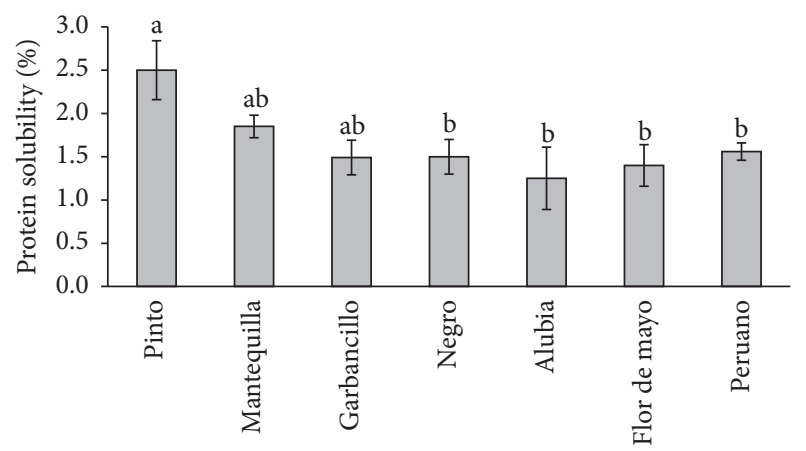

Figure 2: Protein solubility of the tested edible films from the studied bean varieties. Means with the same letter are not significantly $(p>0.05)$ different.

3.4. Film Protein Solubility. Protein solubility of the tested films after $24 \mathrm{~h}$ in an aqueous solution was lower than $3 \%$ for every bean variety studied; however, significant $(p<$ 0.05 ) differences were observed (Figure 2). Proteinaceous edible films from garbancillo, negro, flor de mayo, and peruano varieties show low values of film protein solubility $(1.49 \pm 0.2$ to $1.25 \pm 0.33 \%)$ while in contrast protein solubility of edible films from pinto beans was $2.5 \pm 0.34 \%$. These results demonstrated that the proteinaceous polymers obtained had high polymeric stability, which was enhanced by thermal denaturation treatment of the emulsion $\left(60^{\circ} \mathrm{C}\right.$ for $20 \mathrm{~min}$ ). During heat treatment, parts of the threedimensional structure of the proteins were unfolded, and parts of the hydrophobic residues, -SH groups, and S-S bonds, which were buried inside before heating, were exposed to water. When the molecular distances were close enough to each other, intermolecular polymerization occurred through molecular forces of -SH, S-S interchange reactions, and/or hydrophobic bonds, resulting in an intermolecular network that could be partly responsible for the insolubility of the film in water [38]. The results obtained in this study with regard to protein solubility were lower than values reported for other edible films from other legumes like edible films obtained from mung bean proteins by Bourtoom [9], where protein solubility was $32.96 \%$ prepared under similar conditions, with sorbitol as a plasticizer. Jangchud and Chinnan [31] obtained a value of $20.09 \%$ of protein solubility for peanut protein films, where glycerol was used in a $3: 5$ proportion (protein: glycerol). Instead, protein solubility values less than $5 \%$ for heat-denatured whey protein films were obtained by Pérez-Gago and Krochta [36] and Pérez-Gago and others [37], which is similar to our results.

3.5. Mechanical Properties of Films. Table 2 shows that the percentage of puncture strength decreased with decreasing elongation for the majority of tested proteinaceous edible films. The proteinaceous films from flor de mayo beans exhibited the best mechanical properties with the highest values of puncture strength and elongation; films from negro beans showed similar values for puncture strength, which were significantly different $(p<0.05)$ from the tested films of other studied bean varieties. On the other hand, elongation 


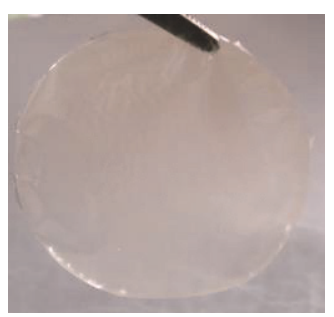

Alubia

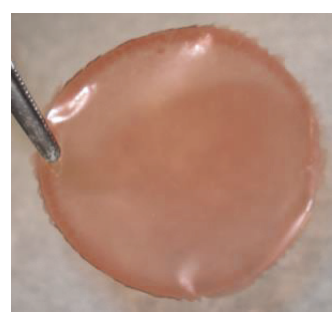

Flor de mayo

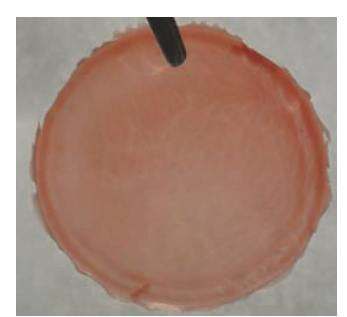

Garbancillo

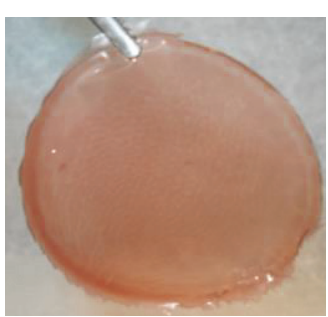

Mantequilla

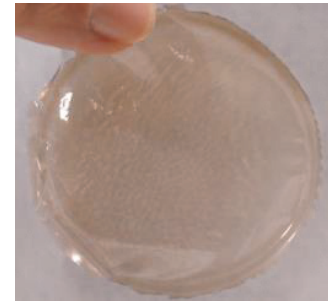

Negro

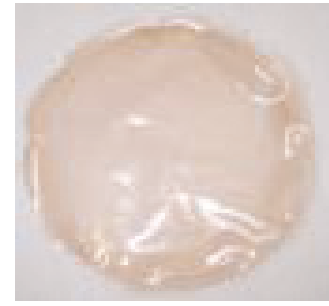

Peruano

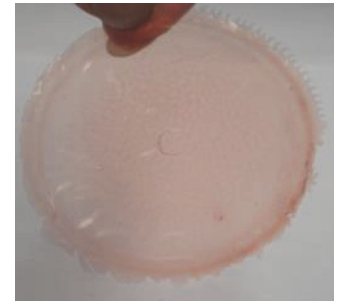

Pinto

FIGURE 3: Color of proteinaceous edible films obtained from the studied bean varieties.

TABLE 2: Mechanical properties of the tested proteinaceous edible films obtained from the studied bean varieties ${ }^{\mathrm{a}}$.

\begin{tabular}{lcc}
\hline Bean variety & $\begin{array}{c}\text { Puncture strength } \\
(\mathrm{MPa})\end{array}$ & Elongation (\%) \\
\hline Alubia & $12.22 \pm 2.09^{\mathrm{cd}}$ & $22.91 \pm 0.26^{\mathrm{e}}$ \\
Flor de mayo & $17.35 \pm 0.82^{\mathrm{a}}$ & $38.21 \pm 0.64^{\mathrm{a}}$ \\
Garbancillo & $14.23 \pm 0.21^{\mathrm{bc}}$ & $24.39 \pm 2.39^{\mathrm{de}}$ \\
Mantequilla & $13.55 \pm 0.97^{\mathrm{cd}}$ & $29.97 \pm 1.98^{\mathrm{bc}}$ \\
Negro & $17.32 \pm 0.06^{\mathrm{ab}}$ & $33.63 \pm 2.03^{\mathrm{b}}$ \\
Peruano & $12.14 \pm 2.77^{\mathrm{cd}}$ & $29.64 \pm 1.98^{\mathrm{bc}}$ \\
Pinto & $10.74 \pm 0.69^{\mathrm{d}}$ & $27.74 \pm 1.46^{\mathrm{cd}}$ \\
\hline
\end{tabular}

${ }^{a}$ Means followed by the same letter in the same column are not significantly $(p>0.05)$ different.

values obtained for edible films from flor de mayo, negro, mantequilla, and peruano beans were significantly $(p<0.05)$ higher than values obtained for films from the rest of the studied beans. These films showed high moisture content; this might affect their mechanical properties, since water may have a plasticizing effect by increasing the molecular mobility of the polymer matrix [39]. Osés et al. [40] reported that exposure of whey edible films to $75 \% \mathrm{RH}$ made them less stiff due to the water's plasticizing effect, with respect to those exposed to $50 \% \mathrm{RH}$. Adsorbed water molecules can act as a plasticizer, inducing a decrease in the contact points between polymeric chains and increasing the average mobility of water molecules. Additionally, glycerol as a plasticizer has high hygroscopicity, which results in higher moisture content of the film's matrix. The mechanical properties of the obtained proteinaceous edible films were lower than those reported by Sabato et al. [41], who assessed the puncture strength of whey protein films obtaining values of $31 \mathrm{MPa}$, while Saremnezhad et al. [5] obtained elongation above $40 \%$ for faba bean protein films.
3.6. Color of Films. Most of the proteinaceous edible films obtained from the studied bean varieties showed reddish to lightly brownish colors, while films from alubia and peruano beans were lightly yellowish (Figure 3 ). Table 3 displays the color parameters of the tested edible films; yellowish films showed higher luminosity values than films with reddishbrownish colors, while the combined values of $a^{*}$ and $b^{*}$ exhibited a red-orange hue for most of the tested edible films. Edible films with the highest content of red color were obtained from flor de mayo beans, which were significantly different $(p<0.05)$ from the other studied bean varieties. Edible films with higher values of $b^{*}$ were made from mantequilla beans, which showed the highest chroma values. These colorations could be due to anthocyanin contents of the studied beans that contributed to the color of the tested films. Salinas-Moreno et al. [20] reported anthocyanins in the grain and seed coat of beans; these compounds belong to the group of phenolic compounds, particularly flavonoids, which are characterized by their solubility in water. The anthocyanins present in the studied beans are of the simple and nonacylated type that are not stable against $\mathrm{pH}$ changes as acylated anthocyanins; however, they are considered valuable as antioxidants. The outstanding antioxidant capacity of the bean varieties with pink and beige colored seed coats (flor de mayo and pinto) was explained by their anthocyanin content by Iniestra-González et al. [42]. For this reason, the different color shades and intensities displayed by the tested proteinaceous edible films from the studied beans are important and could have application in foods sensitive to light; furthermore, the tested films can also be used to enhance the presentation of selected food products. It is important to note that the color of the films embodies pigments extracted along with the bean protein concentrates, mainly attributed to the beans' coats since whole beans were utilized and the bean seed coat was not removed; different colors possibly will be obtained if it is removed before preparation of bean protein concentrates. 
TABLE 3: Color values of the tested proteinaceous edible films obtained from the studied bean varieties ${ }^{\mathrm{a}}$.

\begin{tabular}{lccccc}
\hline Bean variety & $L^{*}$ & $a^{*}$ & $b^{*}$ & Chroma & Hue \\
\hline Alubia & $15.40 \pm 0.23^{\mathrm{a}}$ & $-0.66 \pm 0.03^{\mathrm{e}}$ & $2.37 \pm 0.21^{\mathrm{c}}$ & $2.46 \pm 0.21^{\mathrm{d}}$ & $105.72 \pm 0.92^{\mathrm{a}}$ \\
Flor de mayo & $11.31 \pm 0.28^{\mathrm{de}}$ & $2.84 \pm 0.25^{\mathrm{a}}$ & $3.30 \pm 0.28^{\mathrm{b}}$ & $4.37 \pm 0.14^{\mathrm{b}}$ & $49.19 \pm 4.71^{\mathrm{e}}$ \\
Garbancillo & $10.89 \pm 0.26^{\mathrm{e}}$ & $1.36 \pm 0.18^{\mathrm{b}}$ & $2.68 \pm 0.20^{\mathrm{c}}$ & $2.99 \pm 0.17^{\mathrm{c}}$ & $62.95 \pm 3.78^{\mathrm{cd}}$ \\
Mantequilla & $12.41 \pm 0.89^{\mathrm{c}}$ & $1.22 \pm 0.28^{\mathrm{bc}}$ & $5.54 \pm 0.28^{\mathrm{a}}$ & $5.68 \pm 0.32^{\mathrm{a}}$ & $77.70 \pm 2.50^{\mathrm{b}}$ \\
Negro & $12.09 \pm 0.14^{\mathrm{cd}}$ & $0.95 \pm 0.10^{\mathrm{cd}}$ & $2.27 \pm 0.21^{\mathrm{c}}$ & $2.47 \pm 0.18^{\mathrm{d}}$ & $67.16 \pm 3.61^{\mathrm{c}}$ \\
Peruano & $13.77 \pm 0.29^{\mathrm{b}}$ & $0.70 \pm 0.07^{\mathrm{d}}$ & $2.52 \pm 0.14^{\mathrm{c}}$ & $2.62 \pm 0.11^{\mathrm{cd}}$ & $74.43 \pm 2.41^{\mathrm{b}}$ \\
Pinto & $14.40 \pm 0.47^{\mathrm{b}}$ & $1.29 \pm 0.12^{\mathrm{b}}$ & $2.33 \pm 0.21^{\mathrm{c}}$ & $2.67 \pm 0.16^{\mathrm{cd}}$ & $60.76 \pm 4.31^{\mathrm{d}}$ \\
\hline
\end{tabular}

${ }^{a}$ Means followed by the same letter in the same column are not significantly $(p>0.05)$ different.



(a)

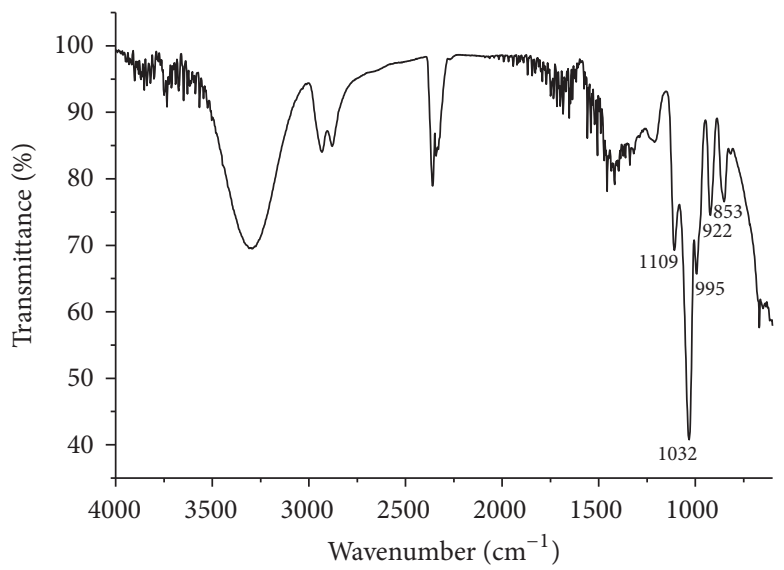

(b)

FIGURE 4: Fourier transform infrared spectra of negro bean protein concentrate (a) and pure glycerol (b).

3.7. Infrared Spectroscopy. The FTIR spectrum of negro bean protein concentrate is shown in Figure 4(a). The main absorption band of peptide linkage is related to $\mathrm{C}=\mathrm{O}$ stretching at $1630 \mathrm{~cm}^{-1}$ (primary amide), N-H bending at $1530 \mathrm{~cm}^{-1}$ $\mathrm{NH}$ (secondary amide), and $\mathrm{C}-\mathrm{N}$ stretching at $1230 \mathrm{~cm}^{-1}$. The broad band of $3500-3000 \mathrm{~cm}^{-1}$ is attributable to free and bound $\mathrm{OH}$ and $\mathrm{NH}$ groups, which are able to form hydrogen bonds with the carbonyl group of the peptides in the proteins [14, 43]. Protein concentrates from other studied bean varieties showed the same type of infrared spectra (data not shown). Figure 4(b) displays the characteristic peaks representing pure glycerol, observed in the wavelength ranges from 800 to $1150 \mathrm{~cm}^{-1}$, where the five peaks correspond to the vibrations of C-C and C-O linkages. The peaks at $853 \mathrm{~cm}^{-1}$, $922 \mathrm{~cm}^{-1}$, and $995 \mathrm{~cm}^{-1}$ are assigned to the vibration of C-C chains, the band at $1032 \mathrm{~cm}^{-1}$ is associated with the extension band of $\mathrm{C}-\mathrm{O}$ in $\mathrm{C}_{1}$ and $\mathrm{C}_{3}$, and the peak at $1109 \mathrm{~cm}^{-1}$ is linked to the extension band of $\mathrm{C}-\mathrm{O}$ in $\mathrm{C}_{2}$.

Edible films from protein concentrates of the studied bean varieties showed the same type of infrared spectra (Figure 5), including edible films from alubia, mantequilla, and negro beans (data not shown). FTIR spectra of edible films demonstrate that no changes took place in the characteristic peaks of protein and glycerol, specifically in the $1200-800 \mathrm{~cm}^{-1}$ region, which indicates that glycerol did not react with the protein through covalent bonds. The peak at $2935 \mathrm{~cm}^{-1}$ is related to the tension band of $\mathrm{C}-\mathrm{H}$ (saturated aliphatic), while the band at $3285 \mathrm{~cm}^{-1}$ is characteristic of the free $\mathrm{OH}$ groups, which are able to form hydrogen bonds. On the other hand, the band at $1400 \mathrm{~cm}^{-1}$, corresponding to the vibrations of $\mathrm{COO}^{-}$group, appears due to the amphoteric character of proteins where the carboxyl group could be ionized since the film forming solution was adjusted at alkaline $\mathrm{pH}$. Guerrero et al. [14] and Guerrero and De La Caba [43] obtained similar FTIR spectral data for soy protein edible films with glycerol as a plasticizer.

\section{Conclusion}

Edible films with lower values of total soluble matter and soluble protein than for other legume protein edible films reported by several authors were obtained from the studied bean protein concentrates. The lowest WVP $(2.06 \times$ $10^{-10} \mathrm{~g} \cdot \mathrm{m} / \mathrm{Pa} \cdot \mathrm{s} \cdot \mathrm{m}^{2}$ ) was observed in the edible films from negro beans; proteinaceous films from flor de mayo had the highest tensile strength (17.35 MPa) and elongation (38.21\%), while the weakest polymeric network was obtained in films from pinto beans. Although some studied bean seed coats were lightly colored (garbancillo, pinto, and mantequilla), the edible films obtained from these varieties were reddish. Proteinaceous films made from negro beans showed the darkest colors while films from peruano and alubia beans were lightly yellowish. Infrared spectra showed that the interaction that 


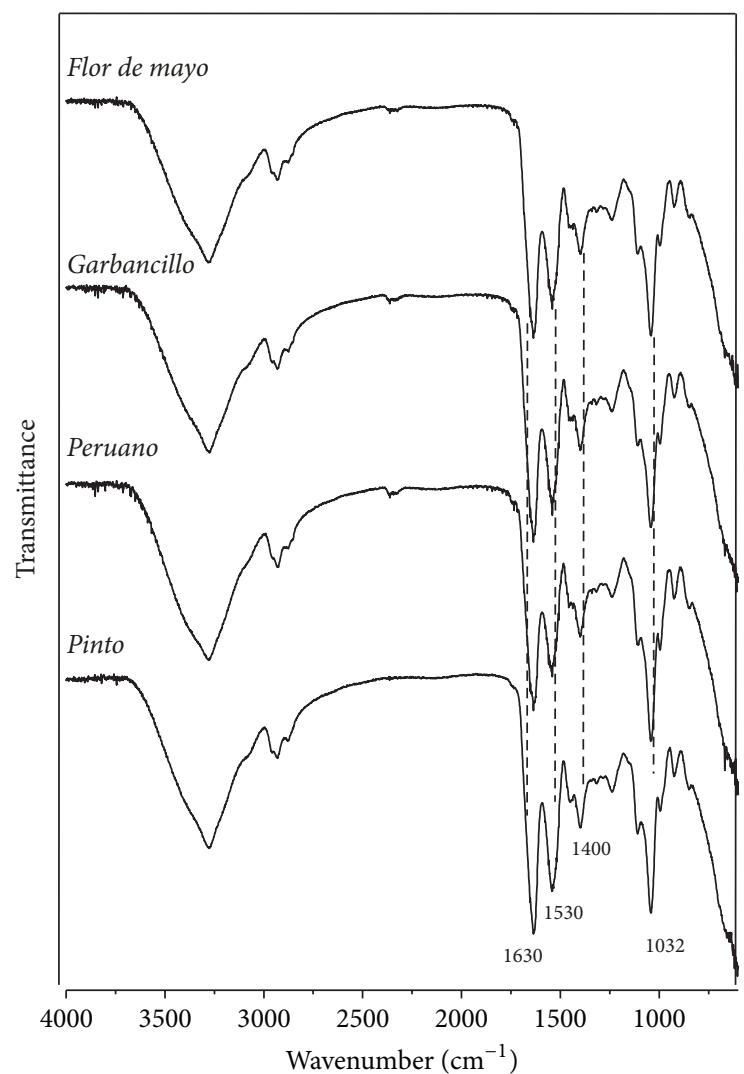

FIGURE 5: Fourier transform infrared spectra of the tested proteinaceous edible films from four of the studied bean varieties.

occurs between the studied protein concentrates and glycerol in the tested films could be due to the presence of hydrogen bonding.

\section{Conflicts of Interest}

The authors declare that they have no conflicts of interest.

\section{Acknowledgments}

The authors would like to acknowledge the financial support from the National Council for Science and Technology of Mexico (CONACyT) and Universidad de las Américas Puebla (UDLAP). The author Montalvo-Paquini acknowledges scholarships for her Ph.D. studies from CONACyT and UDLAP.

\section{References}

[1] J. Sung-Ae, L. Geum-Ok, and B. S. Kyung, "Preparation and mechanical properties of edible rapeseed protein films," Journal of Food Science, vol. 76, pp. C218-C222, 2011.

[2] P. Guerrero, T. Garrido, I. Leceta, and K. De La Caba, "Films based on proteins and polysaccharides: Preparation and physical-chemical characterization," European Polymer Journal, vol. 49, no. 11, pp. 3713-3721, 2013.

[3] V. M. Hernandez-Izquierdo and J. M. Krochta, "Thermoplastic processing of proteins for film formation-a review," Journal of Food Science, vol. 73, no. 2, pp. R30-R39, 2008.
[4] B. Ghanbarzadeh, M. Musavi, A. R. Oromiehie, K. Rezayi, E. Razmi Rad, and J. Milani, "Effect of plasticizing sugars on water vapor permeability, surface energy and microstructure properties of zein films," LWT-Food Science and Technology, vol. 40, no. 7, pp. 1191-1197, 2007.

[5] S. Saremnezhad, M. H. Azizi, M. Barzegar, S. Abbasi, and E. Ahmadi, "Properties of a new edible film made of faba bean protein isolate," Journal of Agricultural Science and Technology, vol. 13, no. 2, pp. 181-192, 2011.

[6] J.-L. Audic and B. Chaufer, "Influence of plasticizers and crosslinking on the properties of biodegradable films made from sodium caseinate," European Polymer Journal, vol. 41, no. 8, pp. 1934-1942, 2005.

[7] C. Andreuccetti, R. A. Carvalho, and C. R. F. Grosso, "Effect of hydrophobic plasticizers on functional properties of gelatinbased films," Food Research International, vol. 42, no. 8, pp. 11131121, 2009.

[8] L. Natthaporn, P. Thummanoon, B. Soottawat, and P. Surasit, "Properties of biodegradable blend films based of fish myofibrillar protein and polyvinyl alcohol as influenced by blend composition and pH level," Journal of Food Engineering, vol. 100, pp. 85-92, 2010.

[9] T. Bourtoom, "Factors affecting the properties of edible film prepared from mung bean proteins," International Food Research Journal, vol. 15, no. 2, pp. 167-180, 2008.

[10] B. Cuq, N. Gontard, and S. Guilbert, "Proteins as agricultural polymers for packaging production," Cereal Chemistry, vol. 75, no. 1, pp. 1-9, 1998.

[11] P. Guerrero, P. M. Stefani, R. A. Ruseckaite, and K. De La Caba, "Functional properties of films based on soy protein isolate and gelatin processed by compression molding," Journal of Food Engineering, vol. 105, no. 1, pp. 65-72, 2011.

[12] G. Denavi, D. R. Tapia-Blácido, M. C. Añón, P. J. A. Sobral, A. N. Mauri, and F. C. Menegalli, "Effects of drying conditions on some physical properties of soy protein films," Journal of Food Engineering, vol. 90, no. 3, pp. 341-349, 2009.

[13] P. Guerrero, Z. A. Nur Hanani, J. P. Kerry, and K. De La Caba, "Characterization of soy protein-based films prepared with acids and oils by compression," Journal of Food Engineering, vol. 107, no. 1, pp. 41-49, 2011.

[14] P. Guerrero, A. Retegi, N. Gabilondo, and K. De La Caba, "Mechanical and thermal properties of soy protein films processed by casting and compression," Journal of Food Engineering, vol. 100, no. 1, pp. 145-151, 2010.

[15] T. Bourtoom, M. S. Chinnan, P. Jantawat, and R. Sanguandeekul, "Effect of select parameters on the properties of edible film from water-soluble fish proteins in surimi wash-water," LWT- Food Science and Technology, vol. 39, no. 4, pp. 405-418, 2006.

[16] D. Kowalczyk and B. Baraniak, "Effects of plasticizers, pH and heating of film-forming solution on the properties of pea protein isolate films," Journal of Food Engineering, vol. 105, no. 2, pp. 295-305, 2011.

[17] P. H. Graham and C. P. Vance, "Legumes: importance and constraints to greater use," Plant Physiology, vol. 131, no. 3, pp. 872877, 2003.

[18] M. Olvera-Novoa and L. Olivera-Castillo, "Potencialidad del uso de las leguminosas como fuente proteica en alimentos para peces," Avances en Nutrición Acuícola Memorias del IV Simposio Internacional de Nutrición Acuícola, pp. 327-348, 2000.

[19] C. Emani and T. C. Hall, "Phaseolin: Structure and Evolution," The Open Evolution Journal, vol. 1, no. 1, pp. 66-74, 2008. 
[20] Y. Salinas-Moreno, L. Rojas-Herrera, E. Sosa-Montes, and P. Pérez-Herrera, "Anthocyanin composition in black bean (Phaseolus vulgaris L.) varieties grown in México," Agrociencia, vol. 39, no. 4, pp. 385-394, 2005.

[21] O. Romero-Arenas, H. M. A. Damian, T. J. A. Rivera, S. A. Báez, L. M. Huerta, and H. E. Cabrera, "The nutritional value of beans (Phaseolus vulgarisL.) and its importance for feeding of rural communities in Puebla-Mexico," International Research Journal of Biological Sciences, vol. 2, pp. 59-65, 2013.

[22] Servicio de Información y Estadística Agroalimentaria y Pesquera (SIAP), Anuario estadístico de la producción agrícola, 2014, http://www.siap.gob.mx/cierre-de-la-produccionagricola-por-cultivo/.

[23] F. Bamdad, A. H. Goli, and M. Kadivar, "Preparation and characterization of proteinous film from lentil (Lens culinaris)," Food Research International, vol. 39, no. 1, pp. 106-111, 2006.

[24] W.-S. Choi and J. H. Han, "Physical and mechanical properties of pea-protein-based edible films," Journal of Food Science, vol. 66, no. 2, pp. 319-322, 2001.

[25] Y. Zahedi, B. Ghanbarzadeh, and N. Sedaghat, "Physical properties of edible emulsified films based on pistachio globulin protein and fatty acids," Journal of Food Engineering, vol. 100, no. 1, pp. 102-108, 2010.

[26] M. S. Tapia, M. A. Rojas-Graü, F. J. Rodríguez, J. Ramírez, A. Carmona, and O. Martin-Belloso, "Alginate- and gellan-based edible films for probiotic coatings on fresh-cut fruits," Journal of Food Science, vol. 72, no. 4, pp. E190-E196, 2007.

[27] O. H. Lowry, N. J. Rosebrough, A. L. Farr, and R. J. Randall, "Protein measurement with the Folin phenol reagent," The Journal of Biological Chemistry, vol. 193, pp. 265-275, 1951.

[28] R. Sothornvit and J. M. Krochta, "Water vapor permeability and solubility of films from hydrolyzed whey protein," Journal of Food Science, vol. 65, no. 4, pp. 700-703, 2000.

[29] S. Soradech, J. Nunthanid, S. Limmatvapirat, and M. Luangtana-Anan, "An approach for the enhancement of the mechanical properties and film coating efficiency of shellac by the formation of composite films based on shellac and gelatin," Journal of Food Engineering, vol. 108, no. 1, pp. 94-102, 2012.

[30] W. G. Cochran and G. M. Cox, Experimental designs, John Wiley and Sons, New York, NY, USA, 2nd edition, 1992.

[31] A. Jangchud and M. S. Chinnan, "Peanut protein film as affected by drying temperature and $\mathrm{pH}$ of film forming solution," Journal of Food Science, vol. 64, no. 1, pp. 153-157, 1999.

[32] S. Mundi and R. E. Aluko, "Physicochemical and functional properties of kidney bean albumin and globulin protein fractions," Food Research International, vol. 48, no. 1, pp. 299-306, 2012.

[33] H. M. Sánchez-Arteaga, J. E. Urías-Silvas, H. Espinosa-Andrews, and E. García-Márquez, "Effect of chemical composition and thermal properties on the cooking quality of common beans (Phaseolus vulgaris)," CYTA - Journal of Food, vol. 13, no. 3, pp. 385-391, 2015.

[34] A. González, M. C. Strumia, and C. I. Alvarez Igarzabal, "Cross-linked soy protein as material for biodegradable films: synthesis, characterization and biodegradation," Journal of Food Engineering, vol. 106, no. 4, pp. 331-338, 2011.

[35] N. Limpan, T. Prodpran, S. Benjakul, and S. Prasarpran, "Properties of biodegradable blend films based on fish myofibrillar protein and polyvinyl alcohol as influenced by blend composition and pH level," Journal of Food Engineering, vol. 100, no. 1, pp. 85-92, 2010.
[36] M. B. Pérez-Gago and J. M. Krochta, "Denaturation time and temperature effects on solubility, tensile properties, and oxygen permeability of whey protein edible films," Journal of Food Science, vol. 64, pp. 705-710, 2001.

[37] M. B. Pérez-Gago, P. Nadaud, and J. M. Krochta, "Water vapor permeability, solubility, and tensile properties of heatdenatured versus native whey protein films," Journal of Food Science, vol. 64, no. 6, pp. 1034-1037, 1999.

[38] X. Guo, Y. Lu, H. Cui, X. Jia, H. Bai, and Y. Ma, "Factors affecting the physical properties of edible composite film prepared from zein and wheat gluten," Molecules, vol. 17, no. 4, pp. 3794-3804, 2012.

[39] M. J. Fabra, P. Talens, R. Gavara, and A. Chiralt, "Barrier properties of sodium caseinate films as affected by lipid composition and moisture content," Journal of Food Engineering, vol. 109, no. 3, pp. 372-379, 2012.

[40] J. Osés, I. Fernández-Pan, M. Mendoza, and J. I. Maté, “Stability of the mechanical properties of edible films based on whey protein isolate during storage at different relative humidity," Food Hydrocolloids, vol. 23, no. 1, pp. 125-131, 2009.

[41] S. F. Sabato, B. Ouattara, H. Yu et al., "Mechanical and barrierproperties of cross-linked soy and whey protein based films," Journal of Agricultural and Food Chemistry, vol. 49, no. 3, pp. 1397-1403, 2001.

[42] J. J. Iniestra-González, J. Ibarra-Pérez, J. A. Gallegos-Infante, N. E. Rocha-Guzmán, and R. F. González-Laredo, "Antinutritional factors and antioxidant activity in improved varieties of common bean (Phaseolus vulgaris)," Agrociencia, vol. 39, pp. 603610, 2005.

[43] P. Guerrero and K. De La Caba, "Thermal and mechanical properties of soy protein films processed at different $\mathrm{pH}$ by compression," Journal of Food Engineering, vol. 100, no. 2, pp. 261-269, 2010. 


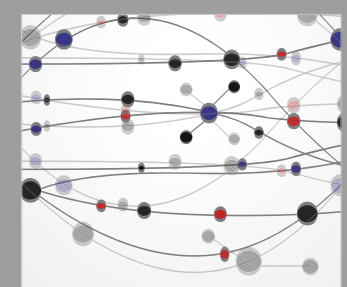

The Scientific World Journal
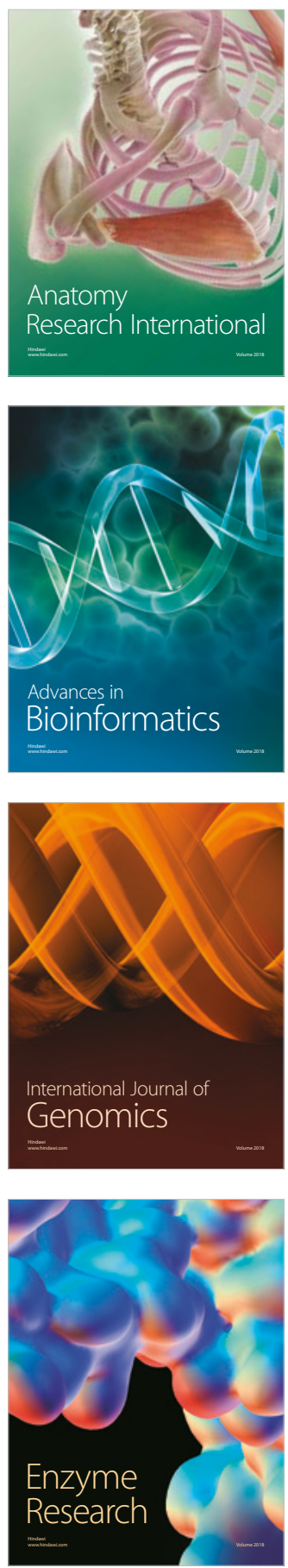
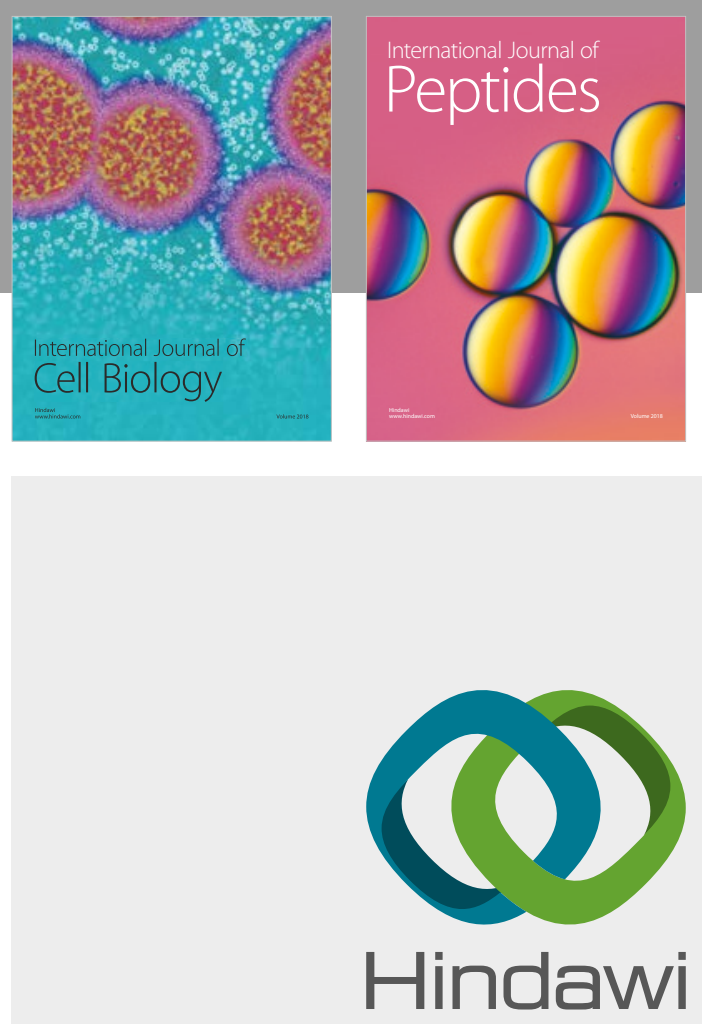

Submit your manuscripts at

www.hindawi.com
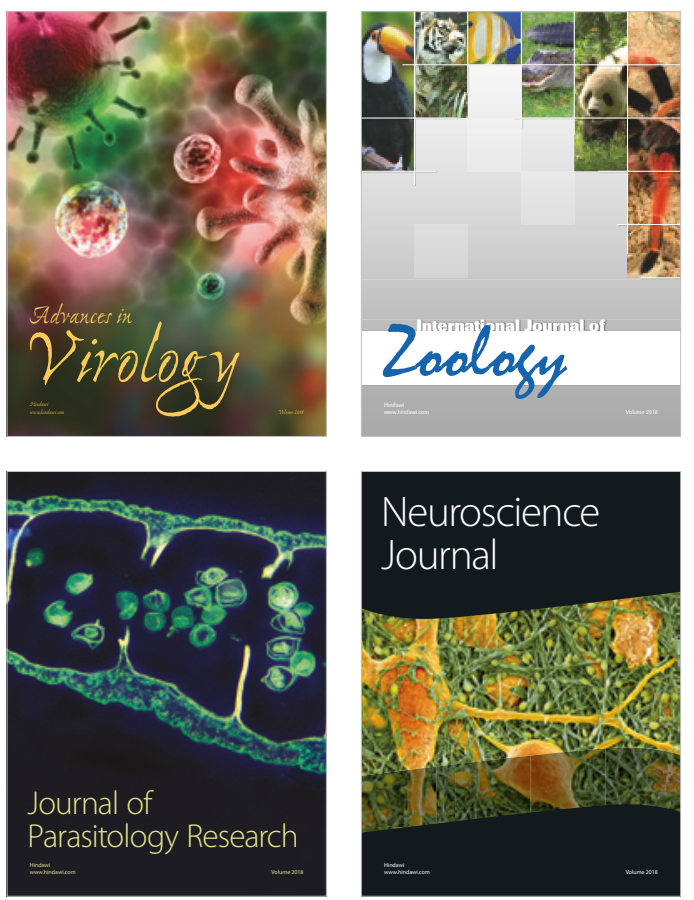
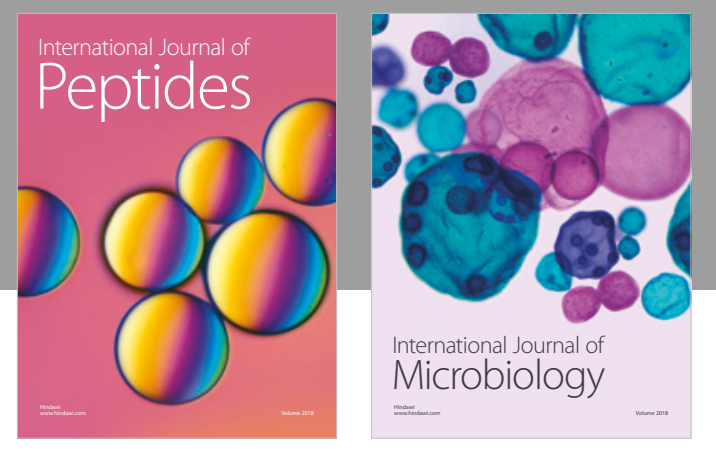

nternational Journal of Microbiology
Journal of
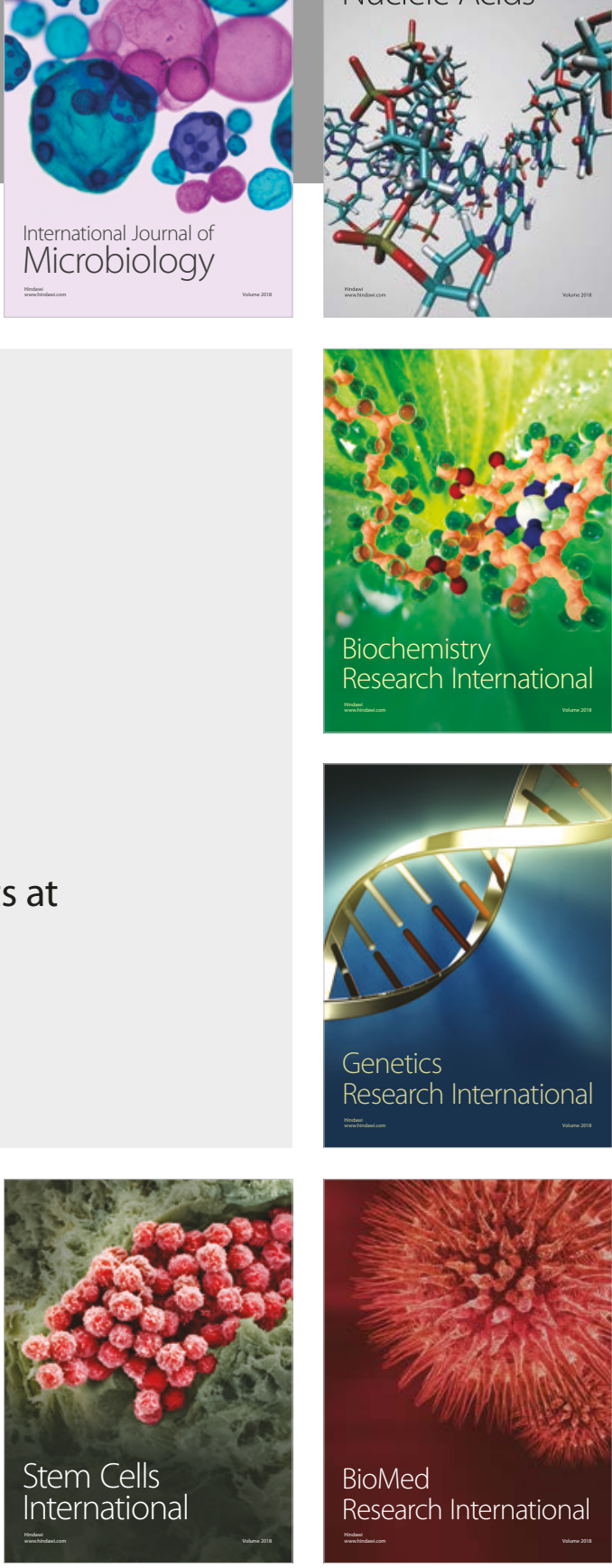
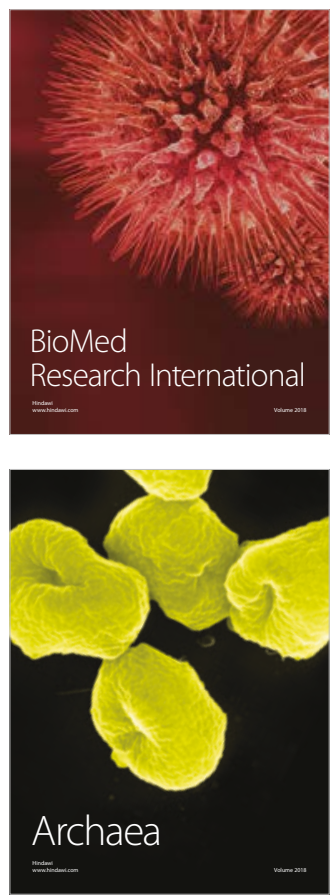